\title{
EXTRACTION, ISOLATION AND PURIFICATION OF VARIOUS COMPONENTS OF CASSIA UNIFLORA AND IT'S IN VITRO STUDIES
}

\author{
V Sowmya ${ }^{1}$, Syed Arbaz Ahmed ${ }^{1}$, Syed Sameer ${ }^{1}$, P. Polireddy $^{1}$, K. Rajeshwari Dutt ${ }^{2}$ \\ ${ }^{1}$ Department of Pharmacology, Nalanda College of Pharmacy, Charlapally (village), \\ Hyd-Road, Nalgonda Dist, Telangana, India. \\ 2 Department of Pharmaceutical Analysis, Nalanda College of Pharmacy, Charlapally (village), \\ Hyd-Road, Nalgonda Dist, Telangana, India. \\ Email: polireddy0004@gmail.com; w.chemistry.687@gmail.com
}

\begin{abstract}
Cassia species are one among the plants to possess great therapeutical value due to their wide rage of pharmacological activities. Hence, in our present study, we have isolated the extract of Cassia uniflora and isolated some important constituents using various solvents among which methanolic extract was optimal. The isolated compounds were also characterized by mass and IR spectroscopy. The extract was further checked for anti-oxidant as well as anti-diabetic activity. From the results obtained, the leaves and fruit extract were found to have good alpha-glucosidase as well as 5-lipoxygenase inhibition.
\end{abstract}

Key words: Cassia uniflora, extract, characterization, anti-oxidant, anti-diabetic

\section{INTRODUCTION}

Cassia species are one among the plants to possess great therapeutical value. ${ }^{[1]}$ Leaves and pods of few species of cassia such as fistula, spectabilis and podocarpa possess laxative as well as antimicrobial activities. ${ }^{[2,3]}$ The seeds and flowering extracts of $C$. auriculata possess antidiabetic activity. ${ }^{[4]}$ Antioxidant activity of $C$. fistula was evaluated by Manonmania, leaves of $C$. nigricans as appetizers, febrifuges and to treat skin infections such as scabies, ringworm and eczema. ${ }^{[5,6]}$ Hepato-protective and anti-inflammatory activity of C. occidentalis, $C$. sophera, and $C$. fistula were also present in the literature. ${ }^{[7]}$ C. italica, C. sophora, C. pumila were reported to possess CNS depressant, anxiolytic as well as hypnotic activity. ${ }^{[8]}$ Barakol was isolated from Cassia siamea having anxiolytic and purgative activity. ${ }^{[9]} C$. mimosoides was reported to possess anti-obese activity. ${ }^{[10]} C$. auriculata, C. tora, C. fistula, C. alata were also reported to possess antioxidant activity and anti-diabetic activity. ${ }^{[11]}$ Among these, another species of cassia (C. uniflora) has has attracted attention for its properties. Nivedita G et al., in 2010 identified various phyto-constituents present in C. uniflora and determined the larvicidal activity against Aedes aegypti. ${ }^{[12]}$ Petroleum ether, methanolic and ethyl acetate extracts of $C$. uniflora were reported to possess analgesic, anti-arthritic as well as anti-inflammatory property. ${ }^{[13]}$ In the present investigation, the plant parts such as fruit, leaf, stems and bark of $C$. unioflora as shown in figure 1, were considered for the study where in we have identified the solvent which extract the components in large quantities and further characterized. The extracts were also studied for their antioxidant as well as anti-diabetic activity.

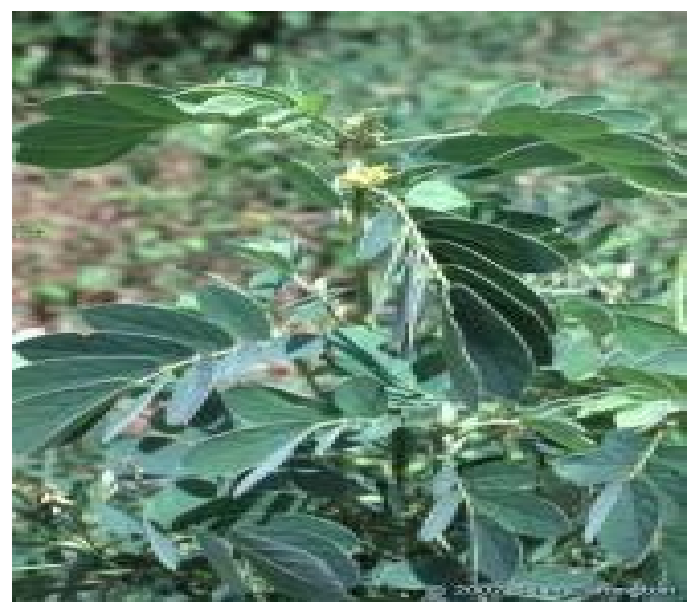

Figure 1: Image of C. uniflora 


\section{MATERIALS AND METHODOLOGY}

\subsection{Plant collection, drying, pulverization and extraction}

Stem, fruit and leaves of C. uniflora were obtained from Rajahmundry region of East Godavari district. They were identified and confirmed by Dr. K. N. Reddy (Taxonomy department) of Laila impex R\&D Centre located in vijayawada. All the plant materials were later deposited in raw drug museum of Laila impex. The plant materials were air dried under shade powdered mechanically to coarse or fine powder. The components were extracted with methanol, water and dil. aq alcohol (60\%) to obtain aqueous, methanolic and hydro alcoholic extracts of various parts of Cassia uniflora. Codes of extracts were named as below and in the further discussion the extracts were mentioned as their codes as seen in table 1.

TABLE 1: EXTRACTION OF C. UNIFLORA

\begin{tabular}{|c|c|c|c|c|c|}
\hline Extract & Crude drug of & Quantity & Extract obtained & Solvent used & Volume \\
\hline CulMeOH & leaf & $100 \mathrm{~g}$ & $20.39 \mathrm{~g}$ & Methanol & $600 \mathrm{ml}$ \\
\hline CulH2OAlc & leaf & $100 \mathrm{~g}$ & $25.71 \mathrm{~g}$ & $60 \%$ methanol in water & $600 \mathrm{ml}$ \\
\hline CulWat & leaf & $100 \mathrm{~g}$ & $30.89 \mathrm{~g}$ & Water & $600 \mathrm{ml}$ \\
\hline CusMeOH & stem & $45 \mathrm{~g}$ & $4 \mathrm{~g}$ & Methanol & $300 \mathrm{ml}$ \\
\hline $\mathrm{CusH2OAlc}$ & stem & $45 \mathrm{~g}$ & $5.55 \mathrm{~g}$ & $60 \%$ methanol in water & $300 \mathrm{ml}$ \\
\hline $\mathrm{CusWat}$ & stem & $45 \mathrm{~g}$ & $6.86 \mathrm{~g}$ & Water & $300 \mathrm{ml}$ \\
\hline CufMeOH & fruit & $35 \mathrm{~g}$ & $4 \mathrm{~g}$ & Methanol & $250 \mathrm{ml}$ \\
\hline CufH2OAlc & fruit & $35 \mathrm{~g}$ & $6 \mathrm{~g}$ & $60 \%$ methanol in water & $250 \mathrm{ml}$ \\
\hline CufWat & fruit & $35 \mathrm{~g}$ & $4.43 \mathrm{~g}$ & Water & $250 \mathrm{ml}$ \\
\hline
\end{tabular}

As methanolic extract of the leaf was obtained in large quantities, various solvent was used to isolate the compounds which include $\mathrm{CH} 3 \mathrm{Cl}, 2 \%, 6 \%, 10 \%, 20 \%$, and 50 acetone in chloroform, acetone and methanol. Chloroform extract was obtained in large quantity $(2 \mathrm{~g})$ which were further subjected to resolute the components.

\subsection{ABTS radical scavenging activity ${ }^{[14]}$}

Radical scavenging activity was performed by following the method described by Re et al., with certain modifications. ABTS (Hi-Media) radical cation was generated by reacting ABTS stock solution $7 \mathrm{mM}$ with $2.45 \mathrm{mM}$ potassium persulfate (final concentration) by dissolving in distilled water (1:1) ratio and the mixture was allowed to incubate $16-20 \mathrm{~h}$ for the formation of ABTS radical cation at room temperature. Prior usage, the prepared solution was diluted using ethanol to get absorbance of 0.700 at $734 \mathrm{~nm}$. Dilutions of plant extracts in various solvents were prepared to obtain concentrations of $100-400 \mu \mathrm{g} / \mathrm{ml}$. The plant extract of varying concentrations with $1 \mathrm{ml}$ of ABTS solution was homogenized and its absorbance was recorded spectrophotometrically (Sican 2301, Inkarp) at $734 \mathrm{~nm}$ by keeping ethanol as a blank and Trolox as positive control. The antiradical activity, ABTS scavenging activity was expressed as IC50 $(\mu \mathrm{g} / \mathrm{ml})$. The \% inhibition of radical scavenging activity was then calculated using the following formula:

$$
\text { ABTS scavanging activity }(\%)=\frac{\text { Negative control absorbance }- \text { Sample absorbance }}{\text { ANegative control absorbance }} X 100
$$

\subsection{Alpha amylase inhibition ${ }^{[16]}$}

The $\alpha$-amylase inhibition was measured by following the method of Adisakwattana et al. with some modification. Porcine pancreatic $\alpha$-amylase (4 units/ml) MP Biomedicals (Cat. No: 191239) was dissolved in 0.1M phosphate buffer of $\mathrm{pH}$ 6.9. Plant extract's stock solutions for inhibition assay were prepared in various concentrations of $100-400 \mu \mathrm{g} / \mathrm{ml}$ and added to the solution containing starch and phosphate buffer of $1 \mathrm{~g} / \mathrm{L}$ and $165 \mu 1$ respectively. Initiation of the reaction was by adding enzyme solution $(75 \mu \mathrm{L})$ to the incubation medium. After 10 min of incubation, termination of the reaction was performed by adding $250 \mathrm{ml}$ dinitrosalicylic (DNS) reagent (which contains mixture of $1 \% 3,5-\mathrm{DNS}$ acid, $0.05 \% \mathrm{Na}_{2} \mathrm{SO}_{3}, 0.2 \%$ phenol and $1 \%$ aq. $\mathrm{NaOH}$ ) and heating at $100^{\circ} \mathrm{C}$ for $10 \mathrm{~min}$. Thereafter, $250 \mu \mathrm{l}$ of $40 \%$ of potassium sodium tartrate (PST) solution was added to the mixtures in order to stabilize the color. After the temperature was dropped down to room temperature, the absorbance was recorded at 540nm using a microplate reader (EnSpire ${ }^{\circledR}$ Multimode Plate Reader). Acarbose was taken as positive control. Inhibitory activity (inhibition \%) was calculated by the following formula:

$$
\% \text { inhibition of } \pm \text { amylase }=(\text { Abs of control })-\frac{(\text { Abs of sample })}{\text { Abs of sample }} \times 100
$$




\subsection{Determination of $\alpha$-glucosidase inhibitory activity}

$\alpha$-glucosidase inhibition was determined using 4-nitrophenyl-alpha-D-glucopyranoside as the substrate. $\alpha$ glucosidase (Sigma Chemical Co St. Louis M.O. USA) solution (0.006\%) was prepared in 0.02M phosphate buffer (pH 6.3). $0.13 \mathrm{ml}$ of enzyme solution was incubated with $0.13 \mathrm{ml}$ of extract and $0.45 \mathrm{ml}$ of $0.02 \mathrm{M}$ phosphate buffer for $1 \mathrm{~h}$ at $25^{\circ} \mathrm{C}$. After pre-incubation, $0.67 \mathrm{ml}$ of $2 \mathrm{M}$ 4-nitrophenyl-alpha-D-glucopyranoside was added to the reaction. The mixture was further incubated for at least $30 \mathrm{~min}$ at the temperature of $30^{\circ} \mathrm{C}$. Reaction termination was done by adding $1 \mathrm{M} \mathrm{Na} 2 \mathrm{CO} 3$ solution $(2 \mathrm{ml})$. Determination of the amount of 4-nitrophenol formed was recorded at $405 \mathrm{~nm}$ using a microplate reader. Inhibitory activity (inhibition \%) was calculated by the following formula:

$$
\% \text { inhibition of glucosidase }=(\text { Abs of control })-\frac{(\text { Abs of sample })}{\text { Abs of sample }} \times 100
$$

\section{RESULTS AND DISCUSSION}

Cassia uniflora stem, fruit and leaves were extracted with methanol, hydroalcohol and water. The Cassia uniflora leaf methanolic extract was selected to carry out further work. The leaf methanolic extract was fractionated by column chromatography and 4 compounds were isolated by fractionation which were identified by mass and IR spectroscopic methods. All the details of the extraction are tabulated in table 2.

\subsection{COMPOUND CulMeOH-1}

The compound CULMEOH-1 was obtained as colourless white crystalline solid mp $180-182^{\circ} \mathrm{C}$. The molecular formula of compound CULMEOH-1 was shown to be $\mathrm{C}_{7} \mathrm{H}_{14} \mathrm{O}_{6}$ based on the Negative ion LC-MS [ $\mathrm{m} / z$ 193(M$\mathrm{H})^{-}$] analysis as in spectrum as can be seen in figure 2. The IR spectrum showed bands at 3403.65,3318 (hydroxyl), $1511.47,1452,1129,1072.47,1002$ and $961 \mathrm{~cm}^{-1}$ (ether). From the above spectral data, physical constants the compound CULMEOH-1 have found to corroborate well with reported data of 3-O methyl D chiro inositol.

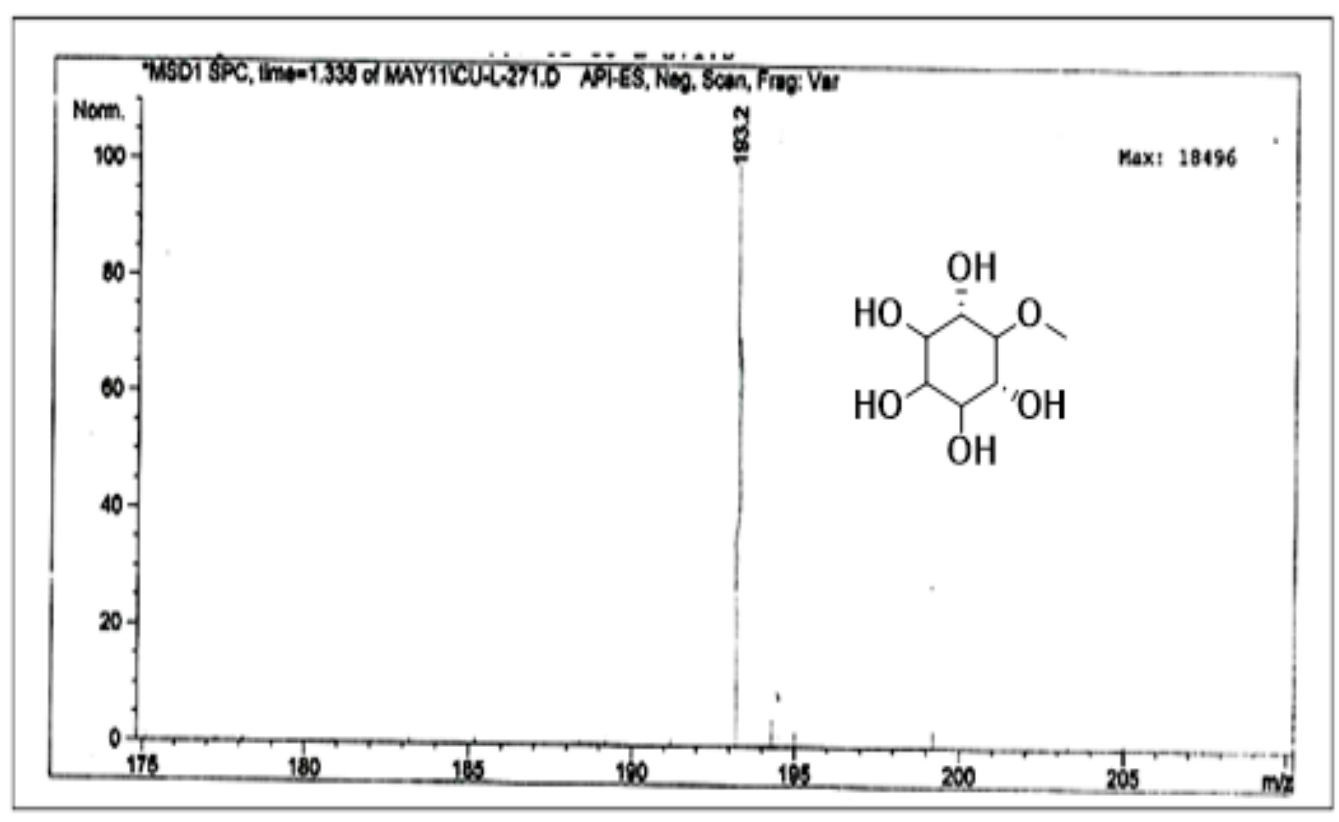

Figure 2: Mass spectra of CulMeOH-1

\subsection{COMPOUND CULMEOH-2}

Compound CULMEOH-2 was obtained as a pale yellow powder from methanol $\mathrm{mp} 328-330^{\circ} \mathrm{C}$ and analyzed for $\mathrm{C}_{15} \mathrm{H}_{10} \mathrm{O}_{6}$ based on the Negative ion LC-MS [m/z 285.2(M-H)-] analysis as in the spectrum shown in figure 3. The IR spectrum showed bands at 3419 (hydroxyl), 2923, 2855.94 symmetric and asymmetric stretching 1655.23 (carbonyl) 1608.83 alkene, 1569.89, $1511.78,1445$ (aromatic),1265.43 and 1166 (C-O). The spectral data and physical constants of compound CULMEOH-2 are well in agreement with reported data of luteolin 


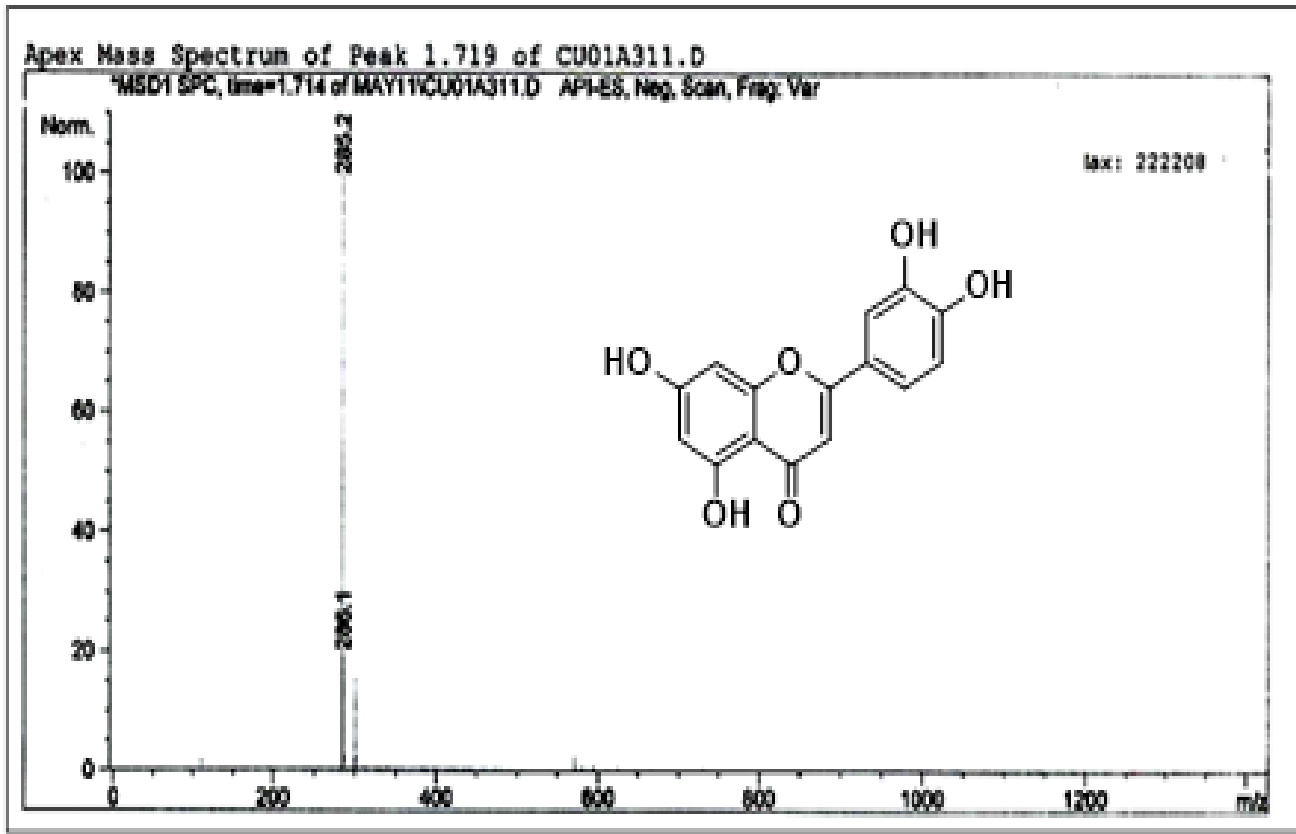

Figure 3: Mass spectra of CulMeOH-2

\subsection{COMPOUND CULMEOH-3}

Compound CULMEOH-3 was obtained as solid; from methanol $\mathrm{mp}>52-55^{\circ} \mathrm{C}$. Based on the positive ion LCMS $\left[\mathrm{m} / \mathrm{z} 353.4(\mathrm{M}+\mathrm{H})^{+}\right]$analysis as in the spectrum shown in figure Z. The IR spectrum showed bands at 2914 , 2846 (C-H stretching symmetric \& asymmetric) 146911407 (C-H bending) 1218 and $1120 \mathrm{~cm}^{-1}$ (C-O stretching) as in the spectrum as shown in figure 4 . The spectra were found to be long chain alkane pentacosane.

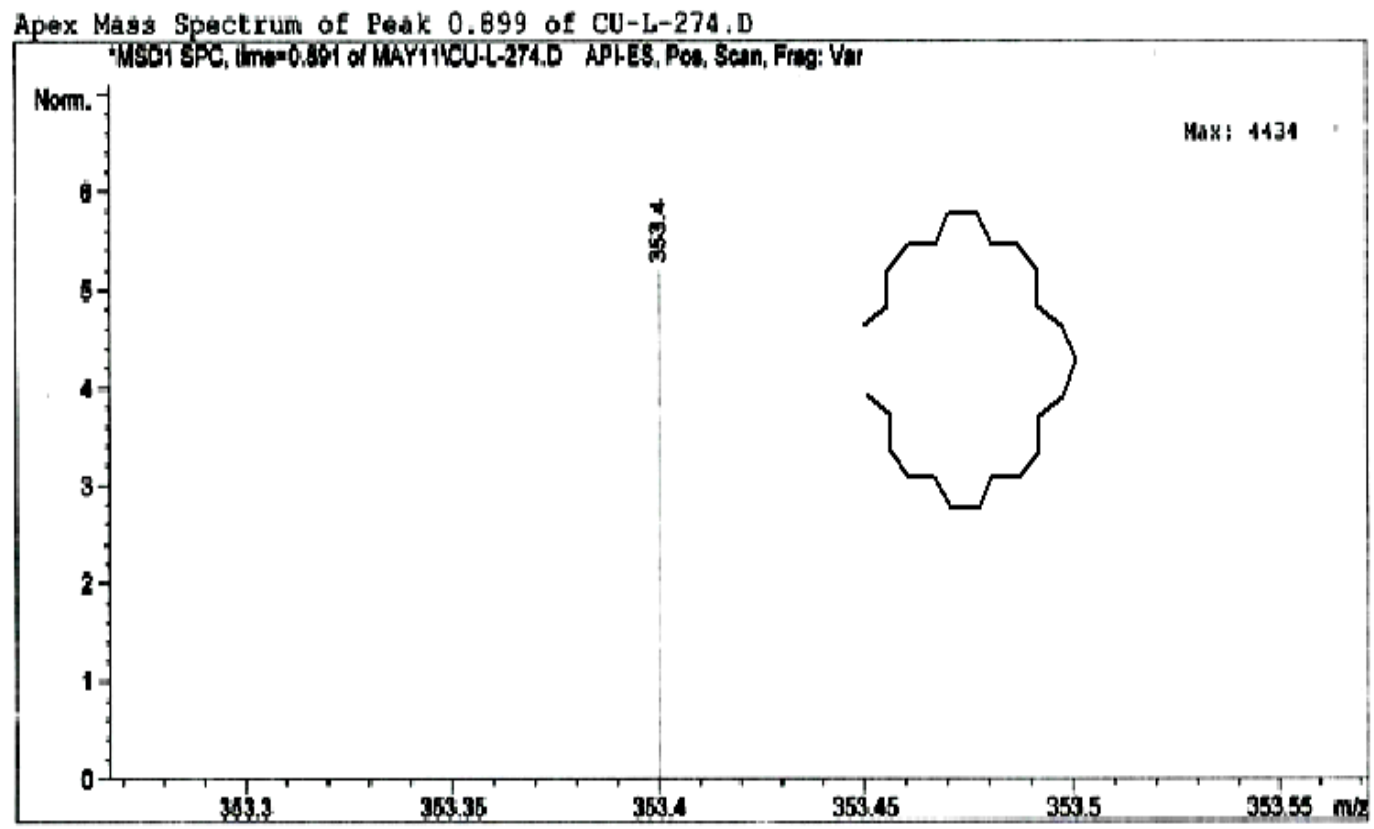

Figure 4: Mass spectra of CulMeOH-3

\subsection{COMPOUND CULMEOH-4}

Compound CULMEOH-4 was obtained as solid; $\mathrm{mp} 82-84^{\circ} \mathrm{C}$. The IR spectrum showed bands at 3398 (hydroxyl), 2914, $2847 \mathrm{~cm}^{-1}$ for $\mathrm{CH}$ strectching 14361359 and $1120 \mathrm{~cm}^{-1}(\mathrm{C}-\mathrm{O})$ as in the spectrum as shown in figure ZA. The molecular formula of compound CULMEOH-4 was shown to be $\mathrm{C}_{30} \mathrm{H}_{62} \mathrm{O}$ based on the positive ion LC-MS $[\mathrm{m} / \mathrm{z}$ 437.8(M-H)-]. The spectra as shown in figure 5, were in accord with those published previously for 1-tricontanol. 


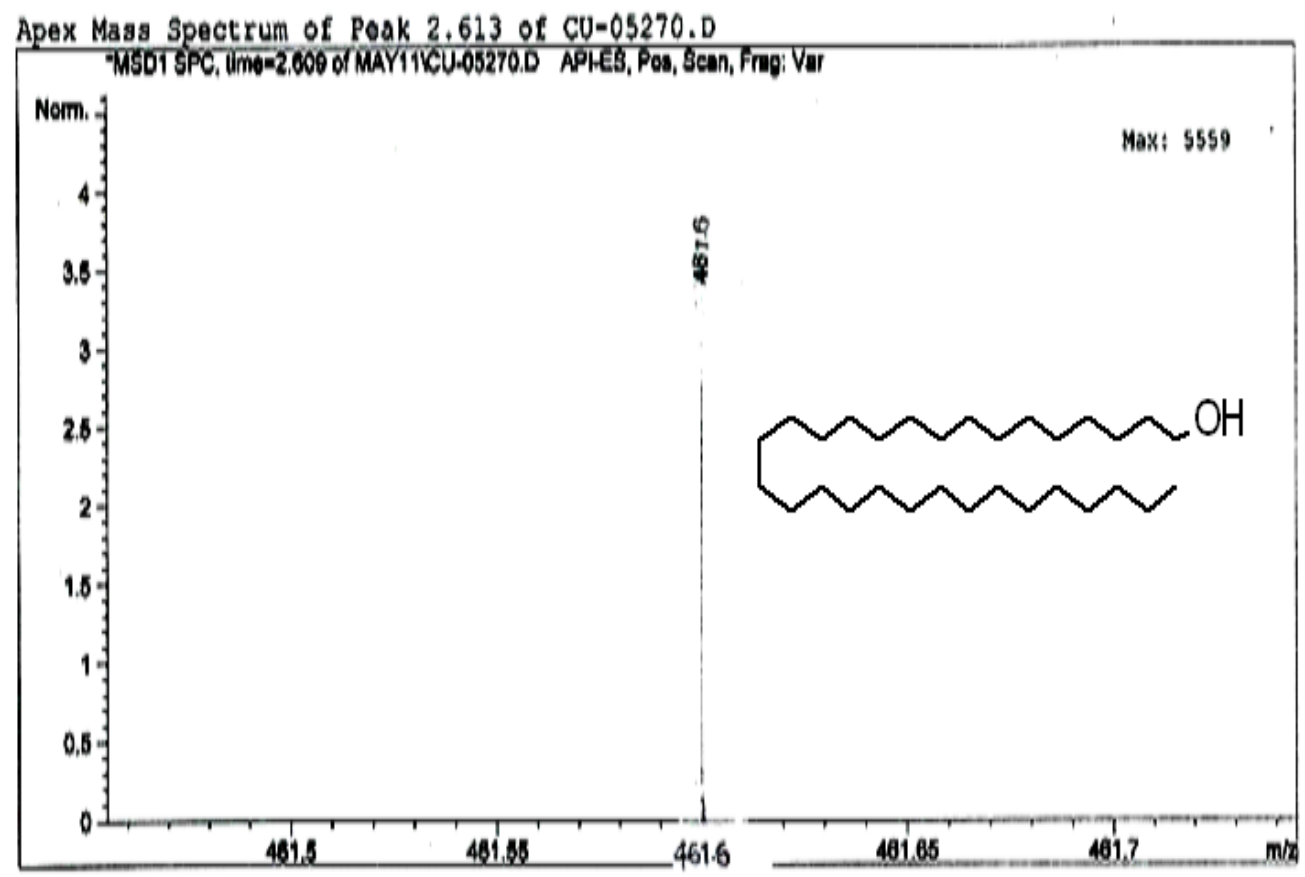

Figure 5: Mass spectra of CulMeOH-4

TABLE 2: DATA OF ISOLATED COMPOUNDS FROM CULMEOH

\begin{tabular}{|l|l|l|l|l|}
\hline & C-1 & C-2 & C-3 & C-4 \\
\hline $\begin{array}{l}\text { Chemical } \\
\text { name: }\end{array}$ & $\begin{array}{l}\text { (1S,2S,4S,5R)-6- } \\
\text { methoxycyclohexane } \\
-1,2,3,4,5-\text { pentol }\end{array}$ & $\begin{array}{l}\text { 2-(3,4- } \\
\text { Dihydroxyphenyl)- } \\
\text { 5,7-dihydroxy-4- } \\
\text { chromenone }\end{array}$ & n-pentacosane & triacontan-1-ol \\
\hline $\begin{array}{l}\text { Common } \\
\text { name: }\end{array}$ & Methyl Inositol & Luteolin & Pentacosane & Melissyl alcohol \\
\hline Physical state: & White crystals & Pale yellow powder & White powder & White powder \\
\hline Melting point: & $180-182^{\circ} \mathrm{C}$ & $328-330^{\circ} \mathrm{C}$ & $52-55^{\circ} \mathrm{C}$ & $82-84^{\circ} \mathrm{C}$ \\
\hline Rf $(\mathbf{c m}):$ & $\begin{array}{l}0.5(\text { solvent system } \\
\text { chloroform:methanol } \\
6: 4)\end{array}$ & $\begin{array}{l}0.75 \text { (solvent system- } \\
\text { chloroform:methanol } \\
8: 2)\end{array}$ & $\begin{array}{l}0.87 \text { (solvent system- } \\
\text { hexane:ethyl acetate } \\
8: 2)\end{array}$ & $\begin{array}{l}0.37 \text { (solvent system- } \\
\text { Hexane:chloroform } \\
8: 2)\end{array}$ \\
\hline
\end{tabular}

\subsection{Biological activity}

Methanolic, hydro alcoholic and aqueous extracts of Cassia uniflora (leaves, fruits and stem parts) were screened for various in-vitro pharmacological assays such as antioxidant, anti-diabetic and anti-inflammatory.

Methanolic, hydro alcoholic and aqueous extracts of leaves, fruits and stems of Cassia uniflora was found to possess good radical scavenging activity with superoxide radical scavenging with $\mathrm{IC}_{50}$ value $25.59 \mu \mathrm{g} / \mathrm{ml}$ against ascorbic acid and gallic acid (DPPH radical scavenging activity) with $\mathrm{IC}_{50}$ value $3.56 \mu \mathrm{g} / \mathrm{ml}$ and 38.41 respectively; whereas, $8.85 \mu \mathrm{g} / \mathrm{ml}$ against ascorbic acid $(3.09 \mu \mathrm{g} / \mathrm{ml})$ and gallic acid $(8.85 \mu \mathrm{g} / \mathrm{ml})$ in case of ABTS scavenging activity as can be seen in figure 6 . 


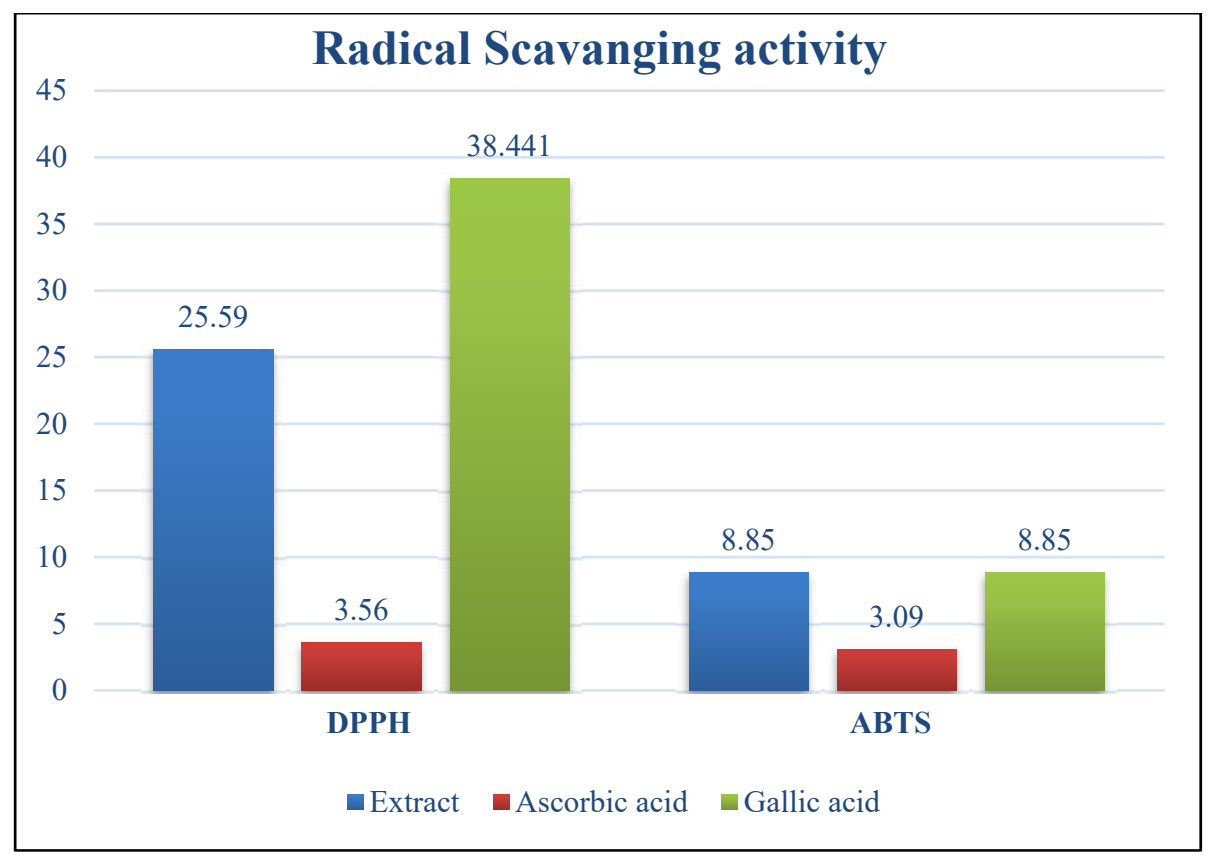

Figure 6: Radical scavenging activity of $\mathrm{CulMeOH}$

Methanolic, hydroalcoholic and aqueous extracts of leaves, fruits and stems of Cassia uniflora were screened for in-vitro antidiabetic activity with alpha-amylase and alpha-glucosidase assay. Amongst leaves methanolic and fruit hydro alcoholic extracts of Cassia uniflora found to possess good alpha-glucosidase activity and alphaamylase activity with $\mathrm{IC}_{50}$ value $5.65 \mu \mathrm{g} / \mathrm{ml}, 5.04 \mu \mathrm{g} / \mathrm{ml}, 275 \mu \mathrm{g} / \mathrm{ml} 264 \mu \mathrm{g} / \mathrm{ml}$, respectively, by comparing the results with standard as Acarbose $\mathrm{IC}_{50}$ value $57 \mu \mathrm{g} / \mathrm{ml}$ (alpha-glucosidase) and $103.27 \mu \mathrm{g} / \mathrm{ml}$ (alpha-amylase) as can be seen in figure 7 and 8 respectively.

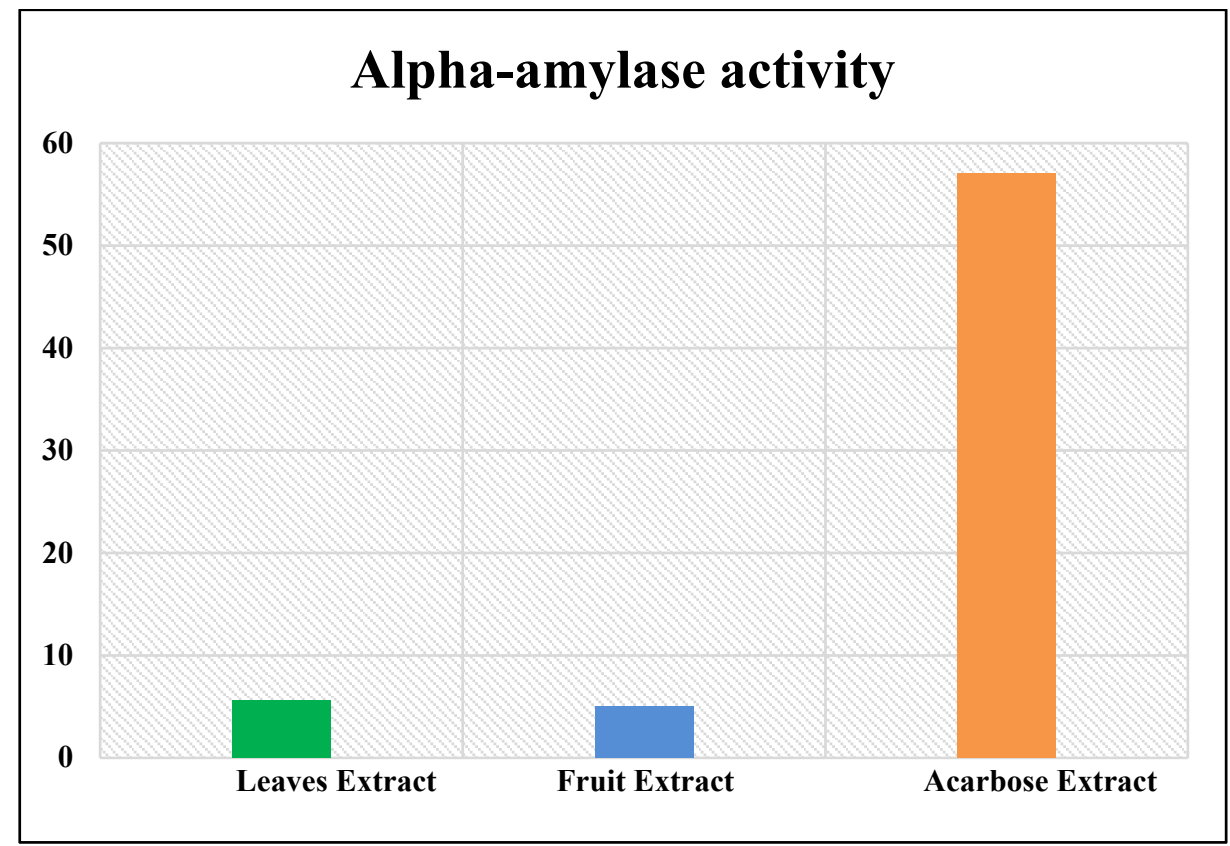

Figure 7: Alpha amylase scavenging activity of $\mathrm{CulMeOH}$ 


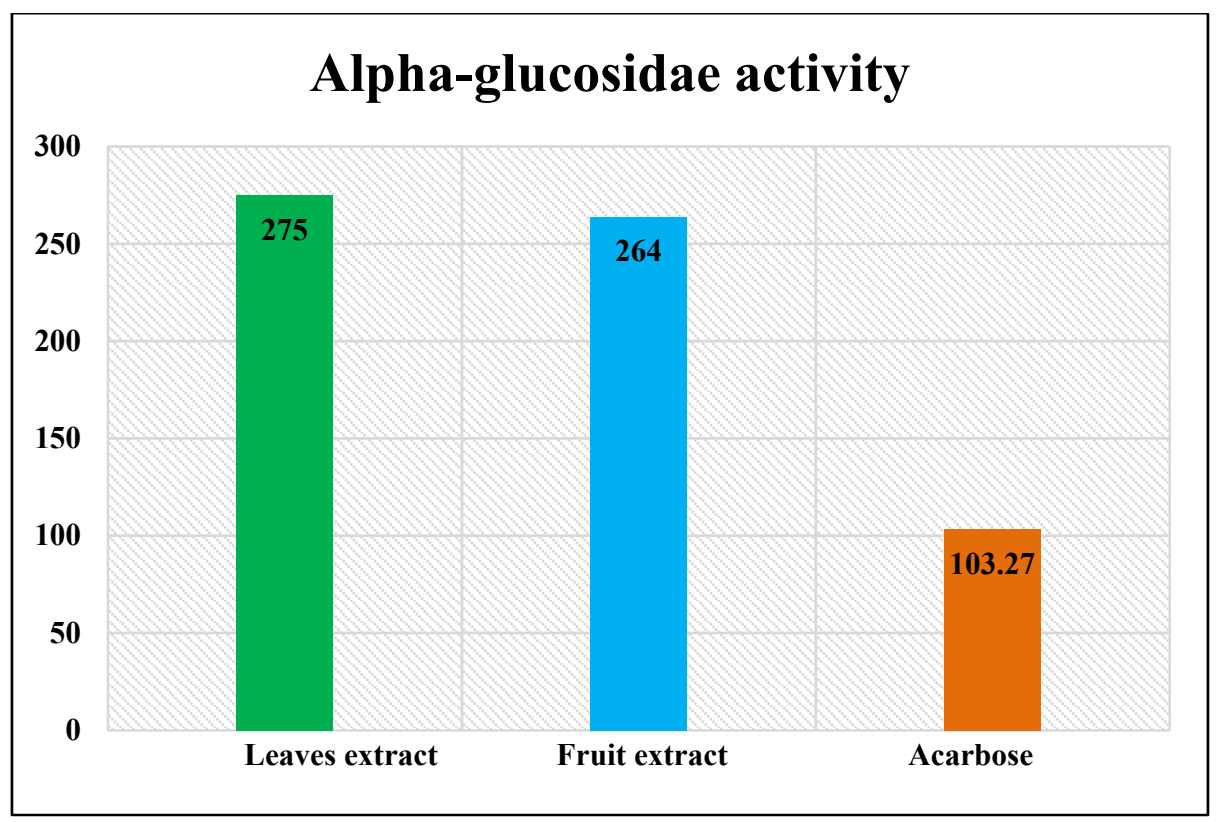

Figure 8: Alpha glucosidase scavenging activity of $\mathrm{CulMeOH}$

Hydroalcoholic extract of leaves, stems and fruits of Cassia uniflora was found to have good 5-lipoxygenase inhibitory activity with $\mathrm{IC}_{50}$ value $47.85 \mu \mathrm{g} / \mathrm{ml}, 46.97 \mu \mathrm{g} / \mathrm{ml}$ and $46.58 \mu \mathrm{g} / \mathrm{ml}$ by comparing the results with standard demethylated curcumin with $\mathrm{IC}_{50}$ value $6.13 \mu \mathrm{g} / \mathrm{ml}$ as can be seen in figure 9 .

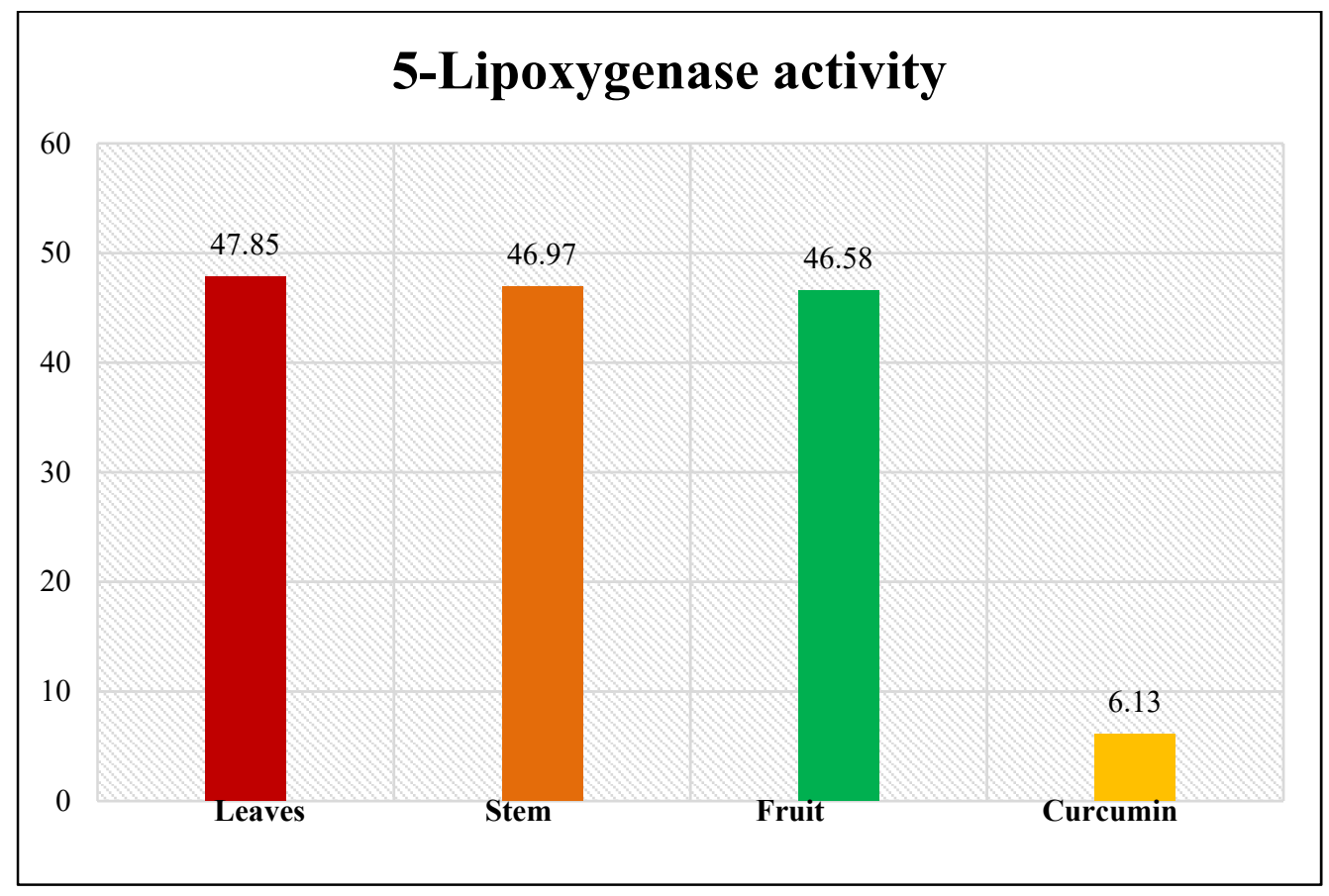

Figure 9: 5-lipoxygenase inhibitory activity of $\mathrm{CulMeOH}$

\section{CONCLUSION}

In consideration with extractive value and In-vitro antioxidant assay, methanolic leaf extract of Cassia uniflora was forwarded to fractionation and column chromatography for isolation of phytoconstituents. The isolated fractions were also screened for ABTS radical scavenging assay and alpha-glucosidase assay. In case of Cassia uniflora leaf 50\% acetone in chloroform and methanol fraction was found to have good ABTS radical scavenging activity, so it was chromatographed for isolation. Compound C-2 (luteoline) was isolated from 50\% acetone in chloroform fraction and compound C-1(methyl inositol) was isolated from methanol fraction. Chloroform fraction was also forwarded to column chromatography and compound C-3(pentacosane), C-4(triacontane-1-ol) was isolated. By comparing the data with standard library these four compounds were identified by IR and LC-MS. 


\section{ACKNOWLEDGEMENT}

The authors are thankful to Nalanda College of Pharmacy to permit us to undergo our research work and also to assist us during our work.

\section{CONFLICT OF INTEREST}

Nil.

\section{REFERENCES}

[1] Singh S, Singh SK, Yadav A. A review on Cassia species: Pharmacological, traditional and medicinal aspects in various countries. American Journal of Phytomedicine and Clinical Therapeutics. 2013;1(3):291-312.

[2] Anton R, Haag-Berrurier M. Therapeutic use of natural anthraquinone for other than laxative actions. Pharmacology. 1980;20(Suppl. 1):104-12.

[3] Hafez SA, Osman SM, Ibrahim HA, Seada AA, Ayoub NA. Chemical Constituents and Biological Activities of Cassia Genus: Review. Arch Pharm Sci ASU. 2019;3(2):195-227.

[4] Pari L, Latha M. Effect of Cassia auriculata flowers on blood sugar levels, serum and tissue lipids in streptozotocin diabetic rats. Singapore Med J. 2002;43(12):617-21.

[5] Siddhuraju P, Mohan PS, Becker K. Studies on the antioxidant activity of Indian Laburnum (Cassia fistula L.): a preliminary assessment of crude extracts from stem bark, leaves, flowers and fruit pulp. Food chemistry. 2002;79(1):61-7.

[6] Chidume FC, Gamaniel K, Amos S, Akah P, Obodozie O, Wambebe C. Pharmacological activity of the methanolic extract of Cassia nigricans leaves. Indian journal of pharmacology. 2001;33(5):350-6.

[7] Chauhan P, Tiwari RC, Bhutiani R, Ahamad F. Study of Aragvadha (Cassia fistula Linn.) with special reference to phytopharmacological properties: An overview. Environment Conservation Journal. 2019;20(1\&2):133-8.

[8] Al-Snafi AE. Medicinal plants with central nervous effects (part 2): plant-based review. IOSR Journal of Pharmacy. $2016 ; 6(8): 52-75$.

[9] Kumar D, Jain A, Verma A. Phytochemical and pharmacological investigation of Cassia siamea Lamk: An insight. The Natural Products Journal. 2017;7(4):255-66.

[10] Yamamoto M, Shimura S, Itoh Y, Ohsaka T, Egawa M, Inoue S. Anti-obesity effects of lipase inhibitor CT-II, an extract from edible herbs, Nomame Herba, on rats fed a high-fat diet. International Journal of Obesity. 2000;24(6):758-64.

[11] Ayo RG. Phytochemical constituents and bioactivities of the extracts of Cassia nigricans Vahl: A review. Journal of medicinal plants research. 2010;4(14):1339-48.

[12] Nivedita G, Anand P, Kondiram D. Larvicidal activity of invasive weeds Cassia uniflora and Synedrella nodiflora. International Journal of Pharma and Bio Sciences. 2010;1(3).

[13] Pandey RK, Pandey P. Anti Arthritic Indigenous Herbal Drugs: Phyto-chemistry and Possible Mechanism. Journal of Global Research \& Technology: Volume. 2020;1(1):1.

[14] Miliauskas G, Venskutonis PR, Van Beek TA. Screening of radical scavenging activity of some medicinal and aromatic plant extracts. Food chemistry. 2004;85(2):231-7.

[15] Nair SS, Kavrekar V, Mishra A. In vitro studies on alpha amylase and alpha glucosidase inhibitory activities of selected plant extracts. European Journal of Experimental Biology. 2013;3(1):128-32. 